\title{
Playing the enemies: Belarus finds in between EU and Russian sanctions regimes
}

\section{Jugar a ser enemigos: Belarús entre los regímenes de sanciones de la UE y Rusia}

\section{Ryhor Nizhnikau}

Senior Researcher in the EU's Neighbourhood and Russia Programme, Finnish Institute of International Affairs, Finland. ryhor.nizhnikau@fiia.fi. ORCID: https://orcid.org/00000002-5833-9707

How to cite this article: Nizhnikau, Ryhor. "Playing the enemies: Belarus finds in between EU and Russian sanctions regimes". Revista CIDOB d'Afers Internacionals, issue 125 (September 2020), pp. 113-137. DOI: doi.org/10.24241/rcai.2020.125.2.113/en

\begin{abstract}
This paper analyses the effects on Belarus of European Union (EU) sanctions against Russia, on the one hand, and Russian sanctions on Ukrainian and EU goods, on the other. International sanctions opened up new political and economic opportunities that the Belarusian authorities sought to capitalise on. But Minsk's attempts to swim between two waters (retaining the benefits Moscow offered while improving relations with the EU) have backfired and distrust towards Minsk has grown in Moscow, Brussels and Kiev. A theoretical approach is made to the foreign policy of small states, before this paper shows how Belarus has been harmed by its attempts to take advantage of EU and Russian sanctions regimes.
\end{abstract}

Key words: sanctions, trust, evasion of sanctions, Belarus, Russia, Ukraine, European Union
Resumen: Este artículo analiza los efectos sobre Belarús de las sanciones de la Unión Europea (UE) contra Rusia, por un lado, y de las que Rusia impuso a los productos de Ucrania y de la UE, por el otro. Las sanciones internacionales generaron nuevas oportunidades políticas y económicas para las autoridades bielorrusas, quienes intentaron aprovecharlas. Sin embargo, ello produjo el efecto contrario. Los esfuerzos de Minsk por nadar entre dos aguas (manteniendo los beneficios que le ofrecía Moscú y mejorando las relaciones con la UE) resultaron contraproducentes y aumentaron la desconfianza de Moscú, Bruselas y Kiev. Tras una aproximación teórica sobre la política exterior de los estados pequeños, este artículo muestra cómo Belarús salió perjudicada de sus intentos por aprovecharse de los regímenes de sanciones de la UE y de Rusia.

Palabras clave: sanctions, trust, evasion of sanctions, Belarus, Russia, Ukraine, European Union 
In 2014, Belarus appeared in the middle of a web of sanctions regimes. The EU, US and Ukraine put a set of sanctions on Russia for the annexation of Crimea and the war in Donbas. Russia embargoed EU's agricultural goods, which cut off major suppliers of fish, fruit and dairy products from its market, and restricted export and import of a variety of goods including oil and oil products to Ukraine.

This article studies the effect of sanctions on Belarusian relations with EU, Ukraine and Russia. Since its independence, Belarusian foreign policy has traditionally been Russia-centred. Belarus was a key ally of Russia and a member of its integration inititiatives. Their bilateral relations were growingly institutionalized, in which the deepening of economic and security cooperation was accompanied by their coordination of foreign policies, including Minsk's support of Russian international initiatives. At the same time, the relations with the West was problem-

In 2014, after the annexation of Crimea by Russia, the war in Donbass and mutually imposed sanctions regimes, Belarus received a possibility to re-structure its relations with EU, Ukraine and Russia. Belarus tried to exploit new regional rivalries.

ridden. Belarus openly accused the $\mathrm{EU}$ and the US in preparing a regime change, whereas the West consistently sanctioned the Belarusian regime for multiple electoral and human rights violations. A thaw in Belarus-EU relations in 2008-2010 was a short-lived exception, which was used to bargain with Russia. It ended with another cycle of sanctions and deepening of the BelarusRussia integration.

The analysis of Belarusian regime's approach to sanctions offers a new insight into the Belarusian foreign policy and the evolution of Belarus relations with EU, Russia and Ukraine after 2014. In 2014, after the annexation of Crimea, the war in Donbass and mutually imposed sanctions regimes, Belarus received a possibility to re-structure its relations with EU, Ukraine and Russia. Belarus tried to exploit new regional rivalries. It showed its intentions to develop better ties with EU and Ukraine. Several studies pointed that Belarus reviewed its relations with the West specifically to withstand Russia's growing pressure, which was conceptualized as "strategic hedging", "soft balancing" and "wedging" (Moshes, 2017; Meister, 2018; Wilson, 2018). Russia's assertiveness caused security concerns in Belarus and required actions to lower its dependence in political, economic and security areas. Sejersen (2019) argued that Russia's pressure even triggered Belarus' selective compliance with the EU sanctions demands. Belarus still expressed commitment to Russia as its main economic and security partner during Russia-West conflict. While Belarus expressed its neutrality on several issues, it pledged to assist Russia in enforcing countersanctions against EU and Ukraine.

Paradoxically, if Belarus achieved some limited success in 2014-2016, these policies backfired in 2017-2019. Belarus relations with the EU and Ukraine stagnated 
and Belarus relations with Russia deteriorated sharply after 2017. As this article shows, persisting violation of the sanctions regime was perceived as boundary challenging within Russia-Belarus alliance by Moscow.

This paper continues as follows: first, it looks at how Belarus used the European and Russian sanctions regimes to recalibrate its foreign policy, and second with what results. The conclusion discusses how sanctions worsened the position of Belarus and have played a key role in re-structuring Belarusian-Russian relations.

\section{Theorizing small states' foreign policy behaviour}

Rationalist, liberal and constructivist perspectives explain foreign policy choices through interests, norms, values, and institutions and highlight conditions that can facilitate or restrict their options (see Pape, 2005; Ross, 2019; Lobell et al., 2015). Several contestation strategies analyze small state's behaviour as a response to rising assymetries and a necessity to increase their relative power. Besides hard balancing and bandwagonning, which are feasible theoretically, hedging and wedging are growingly highlighted as dominant foreign policy options (see for example, Catalinac, 2010). Hedging "aims at reducing or minimizing risks arising from uncertainties in the system, increasing freedom of maneuver" and combines cooperative and competitive strategic instruments to proactively develop new means for achieving goals (Koga, 2018). In turn, a strategy of wedging exploits the existing conflicts to improve a bargaining position (Gnedina, 2015). The success of these strategies depends on a number of conditions including the extent of rivalry between major actors, domestic resources and capabilities, extent of contacts with other external players, and the bargaining abilities (Meister, 2018).

Contestation strategies help to understand the decisions and policies of engagement with rival powers, but they largely miss the ongoing dynamics between the allied states. Intra-alliance opposition framework helps to identify tools and strategies of opposition to allied powers. Three particular tools of intra-alliance opposition - boundary testing, boundary challenging and boundary breaking - are identified (Dursun-Özkanca, 2019). Boundary testing is used to understand mutual preferences and sets behavioral patterns. Boundary challenging aims to carve more freedom and maneuvering space within the alliance. Yet, unlike boundary breaking, which is a phase between intra-alliance opposition and outside opposition to the alliance, even if the ally contradicts the allied hegemon on some issues, it still signals its commitment (Dursun-Özkanca, 2019: chap. 1). 
Trade and particularly sanctions policies, as an integral part of "economic tools of foreign policy” (Baldwin, 1985), can play a crucial role in contestation strategies, intra-alliance opposition or confidence building measures. The third country can use sanctions regimes as a part of hedging, wedging, boundary-testing or boundarybreaking. It can also avoid taking sides to navigate between both sides and/or build a perception of a mediator. Moreover, it can attempt at playing the rivals, use its position as a bargaining chip vis-à-vis its ally and extract benefits from both sides simultaneously. Finally, it can use it to show commitment to its partner.

In both frameworks, trust is a necessary component for successful pursuing of contenstation policies, fostering new cooperation or efficient application of intra-alliance opposition (Pape, 2005). Trust can be defined as a rational process, a psychological or a constructivist concept (Ruzicka and Keating, 2015). The rational choice conceptualization of trust views it as risk-taking, built on "immediate reciprocity" (Haukkala et al., 2019). The actor calculates preferences of a potential partner actor to find mutual interest (Rathbun, 2011). As a constructivist concept, trust derives from joint rules and identities and is built on "diffuse reciprocity" (Ruzicka and Keating, 2015; Booth and Wheeler, 2008). Trust is also a central component of fostering, maintaining or deepening cooperation (Rathbun, 2011). As Pape (2005: 37) underlines, cooperation on a repeated basis "may gradually increase their trust in each other's willingness to cooperate against the unipolar leader's ambitions". However, relations, which suffer from mistrust, require tailor-made confidence-building tools, such as transparency and assurance mechanisms, including Track-I and II diplomacy, to manage mistrust before engaging in fruitful cooperation (Haukkala et al., 2019).

\section{Normalization of Belarus relations with the EU, the United States and Ukraine (2014-2016)}

By the end of 2013, Belarus-West relations reached their lowest point. The Lukashenko regime was under targeted sanctions for rigging elections, violations of human rights and undermining the rule of law. The EU set political and economic conditions for their removal (Portela, 2011). In 2011-2013, there were no high-level contacts between the sides and deep mistrust and antagonism characterized BelarusWest relations. Western policy-makers viewed Belarusian regime the "last dictatorship" and a Russia's proxy.

The mistrust was aggravated by Belarus' use of the rapprochement with the EU as a bargain chip in Belarus-Russia relations and its systematic violations of commit- 
ments. In 2007-2010, Belarus and the EU launched normalization process, during which the EU lifted sanctions. However, as soon as Minsk received additional benefits from Moscow, the relations with the EU were demonstratively frozen. Belarusian regime would also not implement its obligations. For instance, Portela (2011: 498) found that Belarusian compliance with EU demands in 2008-2010 "had been unsatisfactory by any standards". In turn, Belarusian regime defied Western values system, considered NATO and Western democracy promotion policies as its main security and political threats respectively. Belarus-Ukraine relations suffered from mutual distrust as well. Belarus distrusted both the "pro-Russian" and "pro-EU" camps within the Ukraine's elite. The pro-EU elite groups, which were brought to power through what was considered by Minsk a regime change in 2004, was perceived as a part of Western democracy promotion policies and a representative of antagonistic values, while the pro-Russian camp was seen as a rival for Russian energy and financial resources. Under the latter's rule, in 2011 Ukraine joined the EU sanctions against Minsk.

In 2014, political and security concerns following the annexation

In 2014, political and security concerns following the annexation of Crimea and intervention in Donbas prompted a modification of Belarusian foreign policy. Belarus took a "middle ground" in the EU-Russia conflict. of Crimea and intervention in Donbas prompted a modification of Belarusian foreign policy. Belarus took a "middle ground" in the EU-Russia conflict. It maintained its political, economic and security orientation on Russia, but it distanced itself on the conflict and engaged politically with the Ukraine and the EU. Minsk did not support Moscow's position on Ukraine. Contrary to Russia’s position, Aleksandr Lukashenko recognized and established contacts the new leadership. Belarus also did not recognize the annexation of Crimea and backed Ukraine in the beginning of the conflict in May 2014: "I have always supported Ukraine's unity and integrity. We, the Belarusians, are interested in this... The fighters warring against the Ukrainians must be destroyed". (Belovol, 2014a and 2014b). In June 2014, Belarusian president at the inauguration of Petro Poroshenko, non-recognized by Moscow, voiced his ambitions to forge new relationship with Kyiv.

Belarus used an opportunity to restore political, security and economic ties with Ukraine. While Russia sanctioned Ukraine, Belarus increased economic and security cooperation with Ukraine. The parties immediately agreed to a set of confidence building measures to decrease mutual mistrust. Minsk turned into a transport hub for air routes between Ukraine and Russia, when both sides forbad direct air routes. It also provided necessary defence supplies and oil products for Ukraine's military, previously imported from Russia. In July 2014, the agreement was signed to start demarcation of the joint border (Censor.net, 2014). Crucially, Belarus ruled out 
the use of Belarusian territory as place d'armes for potential Russia's military action against Ukraine.

Economy and defence were key areas of cooperation aimed at establishing joint productiona and exchanging technologies. In 2014-2016, Belarus's military export to Ukraine significantly increased (Bohdan, 2015). Several joint enterprises were set up including between Ukraine's "Bohdan" and Belarus's MAZ to produce dual-use trucks. Helicopter and engine producer Motor Sich opened a branch in Orsha. Some accounts highlighted the role of Ukraine in the production of the Belarusian air missile "Aist".

In 2015, the Ukrainian-Belarusian intergovernmental commission for trade and economic cooperation proclaimed to work towards "the creation of conditions for further expansion of the strategic partnership in all spheres of the economy" (Melyantsou et al., 2015). Joint enterprises were foreseen to maintain Ukraine's presence in energy, machinery and agriculture sectors at the Russian market (ibid.). Most importantly, during 2015-2016, Belarus replaced Russia, which embargoed Ukraine, as a key supplier of oil and chemical products. Re-export of Russian oil and oil products would account for 70\% of Belarus's trade (Tut.by, 2018).

The improvement of ties with Kyiv facilitated normalization of relations with the West, which Kyiv actively promoted. Prime Minister of Ukraine Arseniy Yatsenyuk noted in November 2015, "[F] or the European Union, for all of us it is very important not to alienate or isolate Belarus no matter what" (Interfax, 2015). In 2014, Ukraine agreed to select Minsk as a stage for Russia-Ukraine peace talks, which was considered a diplomatic victory for Belarus. Some Ukrainian experts noted that Ukraine deliberately "passed the ball to Lukashenko" to improve his international status (Tut.by, 2015). According to local analysts, it changed Belarus's foreign policy image and convinced of its "situational neutrality" (Melyantsou, 2017). For instance, despite the existing EU sanctions leaders of Germany and France visited Minsk and shook hands with Belarusian president.

The EU and the US government recognized the diplomatic efforts of the Belarusian regime. On February 15, 2016, the EU decided not to prolong the sanctions against the Belarusian regime partially to reward for Belarus' role in the Russia-Ukraine conflict. The US Treasury followed the suit and suspended sanctions against Belarus's key state enterprises, politicians and organizations. Belarusian oil and chemicals producers, such as Belnaftahim, Hrodno Azot and Himvolovno, Naftan and Belshina were removed from blacklists until 2021. Sweden and US Embassies re-opened in Minsk. The EU-Belarus cooperation accelerated. They signed the Mobility Partnership and re-started negotiations on visa facilitation and readmission. Some EU funding possibilities were re-opened. Bilateral visits intensified. In Aleksandr Lukashenko's own words, "since the times of Peter I it is the job of the president to cut a window [to 
Europe]" (Tut.by, 2019). Though he declined to attend the Eastern Partnership ${ }^{1}$ summit and Munich Security Forum, he made visits to Italy and Austria - his first official trips to the EU in years. In July 2016, the OSCE Parliamentary Assembly decided to host its $26^{\text {th }}$ Annual Session in Minsk in July 2017.

A number of top US officials have visited Minsk to discuss Ukraine-Russia conflict and the situation in the region. Visits by the US Congress delegations, Department of State officials preceded the visit of National Security Advisor John Bolton in summer 2019. Belarusian foreign minister noted that Ukraine was a key topic of discussion during the visit of John Bolton and "President Lukashenko offered his thoughts on the situation in Ukraine and his proposals on how to stop the conflict". Belarusian side supported greater US involvement in the conflict resolution (Belta, 2019b). John Bolton summarized, "we don't ask to make a choice between the East and the West. USA respect Belarus' willingness to follow its own way and make input in peace and stability in the region" (ibid.).

Belarus attempted to create, expand and sell itself as a "neutral" platform between EU and Russia, a hub of regional security and donor of regional stability. Ministry of Foreign Affairs and Belarusian GONGOs collaborated to carve a new perception of Belarus' role in regional peace, security and prosperity. During his meetings with the top Western officials Belarusian president often underlined that "We aim at that [peace and prosperity in the region], when formulate peace initiatives and promote ideas, which intend to lower hostilities and foster good neighbourhood relations" (ibid., 2019a). As a Track-II confidence building measure, a pro-regime NGO launched "The Minsk Dialogue" in close cooperation with the state. The regime dubbed the process as "Helsinki-2", a new venue for security dialogue in Europe.

\section{Testing the boundaries of Belarus-Russia allianceafter Crimea (2014)}

Belarus traditionally positioned itself as Russia's main defence, political and economic ally and a key member of the Russia-led integration projects. It stressed its

1. The Eastern Partnership is a dimension to the European Neighbourhood Policy, which aims to achieve the closest possible political and economic association. See more at https://www.consilium. europa.eu/en/policies/eastern-partnership/ 
shared interests and values, common history and identity with Russia. In return for its political loyalty, ideological proximity and participation in economic and security integration projects, Russia provided Belarus with subsidies and assistance, estimated at $\$ 106$ billion in 2005-2015 alone (IMF, 2016). The conditions and attempts to revise the amount of Russia's support would trigger occasional boundary testing primarily trade and financial disputes, however neither side would attempt to break the boundaries of their alliance.

In 2014, when Belarus-West normalization started, Minsk simultaneously signalled its political loyalty and commitment to its alliance with Moscow. At the meeting with governor of St Petersburg in November 2014, Lukashenko stressed that "we can do a lot [for Russia]. Moreover, we have never left Russia alone. We will not leave it now. We will not seek benefits in this situation. It is our Russia, and we will defend it like our territory" (Mir24, 2014). In April 2015, in his Address to the Parliament, he repeated: "If necessary we will stay shoulder to shoulder with Russia" (Belta, 2015).

Previously, the rapprochement with the West fitted the established boundaries of the Russia-Belarus alliance and was not perceived by Moscow as a threat of defection. In 2008, the Belarusian rejection to recognize Georgia's breakaway regions boosted the normalization with West, whichlifted sanctions and the offer of economic support in exchange for minor political liberalization. Belarus used the situation to pressure Moscow to accommodate its economic demands (Portela, 2011). By 2014, Russia did not feel threatened by Belarusian maneuvers in the international arena and even publicly supported the normalization of ties with the West. In August 2015, Russia's foreign minister Sergey Lavrov described the Western sanctions regime against Belarus "the deadend" and called the EU "engage, not isolate" Minsk (Ria Novosti, 2015). Lukashenko repeatedly noted that the leaders of Russia and Belarus have "full mutual understanding" on the issue. Russia "understood" Belarusian decision not to recognize the Crimea. Asked about its non-recognition of Crimea, Vladimir Putin talked against "putting the president of Belarus in a difficult position. He just wants to build good neighbourly relations with Ukraine" (Gazeta.ru, 2020).

If the rapprochement with the West did not become an issue, its rejection to support the sanctions' regime did. After sanctions against Western and Ukrainian producers were imposed in 2014, Russia asked Belarus to help to maintain its countersanctions regime. Russia depended on Belarusian cooperation to enforce the sanctions regime due to the inexistence of Belarus-Russia border and the customs control. For that reason, upon the imposition of Russian countersanctions Vladimir Putin immediately informed his Belarusian colleague of the decision, and asked to support "these steps taken far a sake of economic Russia's security". Minsk confirmed its readiness to perform its ally duties. It committed to ensure full transparency on the borders and expressed determination to stop the transit of EU and 
Ukrainian goods through Belarus into Russia “in the spirit of partnership” (Tut.by, 2014).

Furthermore, Belarus offered Moscow its assistance to withstand new challenges and replace the sanctioned goods with its own products. Aleksandr Lukashenko stressed the intention to help Russian people to avoid deficit and rising prices. "If someone on your [Russian] side want to profiteer, raise prices, it is not our position. We must defend our [Russian] people. Russians struggle, prices rise daily. In Novosibirsk, there is a problem with buckwheat. We have a possibility to send 120 tonnes there. We try to solve your problems" (Mk.ru, 2014).

In the first half of 2015, Russia's import of sanctioned goods dropped by $46 \%$, Belarusian food exports skyrocketed. Belarus expanded its export of a number of food categories, in particular milk and meat products (Dzerzhinskaya, 2015). Belarusian deputy minister of agriculture Leonid Marinich described the new situation a "Klondike". "We are ready to replace Western countries in many food positions. We will increase the production of cheese. [...] We replace Dutch potato, we replace Polish apples - we have everything" (RIA Novosti, 2014).

During 2016, the Belarusian food export continued to grow. The supplies of meat and milk grew in 1.5 times, carrots in 2.6 times and bok choy in 3.3 times. Anomalies also continued to berecorded. For instance, in 2015 Belarus exported to Russia five times more apples than its official annual production. According to Artem Belov, head of Russian Soyuzmoloko (Union of milk producers), Belarusian export to Russia (6.5 million tonnes) was close to its annual production (7.2 million tonnes) in 2016 (Vedomosti, 2017). Belarusian official statistics reported six times smaller amount of exports to Russia.

In 2016, Russian authorities started to voice their concerns. Rosselhoznadzor (Federal Service for Veterinary and Phytosanitary Supervision) regularly announced cases of smuggling or counterfeit. Russia's General Prosecutor's Office, Ministry of Agriculture and Federal Customs Service pointed at numerous violations (Balashova and Novopashina, 2017). Yet, there was no accusations of wrongdoing against Belarusian elite. Russian ambassador to Belarus Alexander Surikov defended Belarus, "Reexport does not happen without Russian business. Majority of violations is import of restricted goods by our firms". He even criticized the Rosselhoznadzor officials for "engaging in politics": "As it stands, someone went to a milk plant and immediately reports online. What for?" (Moskalenko, 2018).

At that time, Aleksandr Lukashenko specifically underlined that Russian leadership was not concerned with Belarusian export: "Putin says: no one interferes with you, process food, but do not allow direct transit. We are directly told that we can process food, buy anything in the West. We agreed with Russian President and Prime Minister that it is not a violation of the embargo. Let us be honest, today when they 
[EU exporters] have problems, they are ready to sell it for nothing. Thanks for that" (Onliner, 2014).

Belarusian officials regularly reported their achievements in combatting the smuggling. According to the head of the Belarusian State Customs Committee Yuriy Senko, Belarus spent 108 thousand hours investigating smuggling cases. In 2014-2018 25 thousand tonnes of sanctioned goods were arrested and 4.7 thousand special operations were held (Kononovich, 2018). Belarusian authorities reported criminal investigations and arrests of criminal groups, coordinated by foreign nationals. Importantly, smuggling, which became a key concern of Russian leadership, was presented as a Belarusian security issue. During the presidential election campaign in 2015, Lukashenko ordered to fortify Belarus-Ukraine border to prevent any smuggling (Bohdan, 2016).

\section{The stagnation of West-Belarus normalization in 2017-2019}

An attempt to simultaneously improve relations with Ukraine and the West and maintain the alliance with Russia did not work for long and eventually failed. The improvement of Belarus-Ukraine relations failed. Ukraine mistrust in Minsk as credible political and economic partner restored fast.

First, Ukrainian leadership realized that Belarus continued to play its part as Russia's security and intelligence partner. Belarusian structures and individuals, reportedly on behalf of Russian counterparts, placed bids to take over sensitive infrastructure including banks and energy generating companies in Ukraine. Belarus became a major transit route for Russian oil and LNG gas and helped to secure the oil pipeline running from Russia to Ukraine via Belarus, which supplies 2 million tonnes of diesel to Ukraine annually, in hands of pro-Russian Ukranian politician Viktor Medvedchuk, who is closely connected to Vladimir Putin. In March 2019, when a Ukrainian court forbad Medvedchuk to own it, a Belarusian businessman Nikolay Vorobey, closely connected to Viktor Lukashenko (elder son of the Belarusian president), became its shell owner (Iaroshevich, 2019).

Second, Belarus-Ukraine relations started to degrade politically. In 2017, Belarus declined entry in the country to a several Ukrainians, which were placed on the entry ban list compiled by Russian authorities, and a Ukrainian national was kidnapped by Russian FSB on its territory. The Vice Speaker of the Verkhovna Rada Iryna Gerashchenko called it "a real disgrace", which "does not add trust to bilateral relations". The 
Ukrainian political commentator Iuriy Butusov wrote that "Belarus hostile actions" confirmed that "Putin controls the Lukashenko regime" (Moshes and Nizhnikau, 2018). Foreign minister Pavel Klimkin advised Ukrainians against travelling to Belarus for security reasons. The joint Russian-Belarusian West-2017 military exercises was seen as a direct security threat by Ukrainian leadership. President Lukashenko also occasionally highlighted Ukraine as "unsafe" and "destabilizing" country (Moshes and Nizhnikau, 2018). Belarus would interrupt border demarcation process several times due to "security risks". In April 2017, the demarcation process was temporarily suspended. Ukrainian MFA accused Belarus of total uncooperativeness (see Moshes and Nizhnikau, 2018). Several Ukraine's top officials called to move the Minsk peace talks away from Belarus due to its "hostile" position to Ukraine (ZN.ua, 2018).

Thirdly, trade partnership, which could have served as a confidence building measure, did not emerge. Originally, joint cooperation were envisioned to share the fruits of access the Russian market. Yet, joint enterprises were not set up, as Belarus attempted to exploit its new trade advantages. In August 2015, Belarus imposed mandatory sanitary

An attempt to simultaneously improve relations with Ukraine and the West and maintain the alliance with Russia did not work for long and eventually failed. Ukraine mistrust in Minsk as credible political and economic partner restored fast. and hygienic certification of Ukrainian products. Belarus and Ukraine launched anti-dumping investigations and imposed quotas. In October 2017, Belarus unilaterally slashed export of oil products in October 2017 to increase the price (Kuiun, 2018).

Belarus significantly increased import of food products. By 2017, Ukrainian export of agriculture to Belarus rose in 4 times compared with 2013, even if Ukraine's economy and trade shrank during that time. In November 2016, according to Ukraine's Fiscal Service Belarusian firms bought 99\% of Ukraine's fruits exports (Palivoda, 2019). As the next section points, most of it would be imported to Belarus and re-sold to Russia in evasion of the sanctions regimes with the direct involvement of the Belarusian elite.

Finally, Belarusian side also adjusted its position on Crimea. Alexander Lukashenko stated that it de facto belongs to Russia and Kiev will never be able to regain it, even when a new generation comes to power in Russia. Later, he ruled out the possibility of returning Crimea to Ukraine: "This question is closed once and for all (Gazeta.ru, 2020).

The normalization with the West did not bring a breakthrough as the EU and Belarus relations stagnated. After the sanctions were lifted, the rapprochment quickly hit the ceiling. The sides engaged in a discussion of a new basic partnership agreement and agreed on the visa facilitation, yet Belarus's ambitions to receive financial and 
economic support did not materialize. Belarus rejected any conditional cooperation and openly refuted EU's expectations of minor political and economic liberalization in exchange for assistance. As Aleksander Lukashenko warned the foreign minister of Finland, the chair in the Council of the EU at that time, "not to put forward any conditions for us".

During that time, Belarusian motivation of engagement with the West evolved. In 2014-2016, its hedging tactics was security-oriented and aimed to prevent the deepening of Russian domination. It was seen as an insurance policy against unpredictable Russia. In words of Belarusian president NATO and the West could guarantee Belarusian independence (RBC, 2019). In 2017-2019, motivation changed. Belarus primarily attempted to monetize its "neutrality" playing on the West's security concerns. During that time, pro-regime actors explained that the EU should support Belarus financially unconditionally to preserve its independence. In February 2020, these sentiments were summed up by editorial in the Washington Post (2020), which called to unconditionally support the regime to help it to resist Moscow.

However, the EU and IMF declined to offer unconditional assistance, which caused outbursts and expressions of deep mistrust of its Western counterparts by official Minsk. Belarusian regime's talking heads underlined the West's attempts to organize several Maidans in Belarus. In late March 2017, during the wave of socioeconomic protests, Aleksandr Lukashenko accused the West of trying to overthrow him: "They want to raise a mutiny. Their dream is to destroy the government and oust the president" (DW, 2017). Symbolically, if in 2016 parliamentary elections, two opposition candidates were allowed to join the powerless parliament, as a gesture of "good will" to Brussels, in 2019, only pro-regime candidates were handpicked for office.

\section{Breaking the boundaries of Russia-Belarus alliance in 2017-2019}

While relations with Ukraine and the West did not bring a breakthrough, relations with Russia plummeted. In 2015, at the summit of the Eurasian Economic Union in Hrodno, Russian Prime Minister Dmitry Medvedev addressed the smuggling issue in a light fashion commenting that "unfortunately, we have not been given Belarusian oysters and jamon (...) But everything else was of top quality” (RIA Novosti, 2018). By 2019, the stance and the language of the Russian side sharpened considerably. On February 1, 2019, at the intergovernmental summit of the Eurasian Economic 
Union Dmitry Medvedev directly accused his Belarusian colleague Sergey Rumas of Belarus' profiteering from illegal smuggling of Western sanctioned goods to Russia. In words of Russian Minister of Economic Development Maksim Oreshkin, "Prime Minister of Belarus expressed his doubts that this happens - and in response Dmitriy Anatolievich [Medvedev] put forward documental proof with concrete facts, items and companies involved" (Belsat, 2019a).

The Belarus' role in the violation of the sanction regime played a significant part in the deterioration of the Belarus-Russia relations. Belarusian attempts at hedging came at no surprise to Moscow and largely repeated the events of 2008-2010. The nonrecognition of the Crimea did not violate any existing commitments. Yet, the participation in the smuggling of sanctioned good despite the commitment to prevent it was seen as an act of disloyalty. In 2018, Russian finance minister Anton Siluanov directly noted that the role of Belarus in smuggling played a decisive role in the change of Russia's attitudes to its ally: "We talk about Belarusian side as our neighbour, our ally, but lately our trust has eroded. All these sanctioned goods go to us (...) and flood our markets" (ibid., 2018).

Since 2016, Russia consistently pointed at multiple violations of sanctions regime and requested Belarus to address them. In December 2017, at

The Belarus' role in the violation of the sanction regime played a significant part in the deterioration of the Belarus-Russia relations. Belarusian attempts at hedging came at no surprise to Moscow and largely repeated the events of 2008-2010. Yet, the participation in the smuggling of sanctioned good despite the commitment to prevent it was seen as an act of disloyalty. the forum "Greenhouses of Russia”, head of Rosselhoznadzor Sergey Dankvert pointed that Belarusian milk export is an anomaly and "perhaps they scam out of some greediness" (ibid., 2017). If in 2016, Rosselhoznadzor occasionally announced that they cancelled planned inspections in Belarus (Vedomosti, 2017), in 2017 its checks increased. Sanctions on milk, meat and fruit producers were imposed, when irregularities were found. Yet, as soon as one loophole was closed, a new one appeared. For example, when import from Minsk region was disallowed, the import from Mahilou region immediately grew by 30\% (RBC, 2018).

In August 2017, Russian Custom Service identified a large network of re-exporters, which were connected to the Belarusian largest logistic company Beltamozhservis (ibid., 2018). During 2018 Rosselhoznadzor "found systematic supplies of sanctioned goods disguised as Belarusian and accompanied by sanitary certificates, provided by Belarusian state sanitary service” (Belsat, 2019b). In December 2018-February 2019, Russia identified 31 state farms exporting apples without their own production bases and re-selling production "grown in the EU or Ukraine" (ibid., 2019a). In 2019, Ros- 
selhoznadzor discovered a "fake transit" scheme involving over 36 Belarusian companies (Naviny.by, 2019).

Russian official rhetoric harshened considerably, in which smuggling became one of central elements. Then new Russian ambassador to Minsk Mihail Babich started to systematically point at the Belarusian involvement in sanctions evasion: "Russian budget loses hundreds of millions from Belarus re-export of sanctioned goods by fake transit, smuggling or VAT manipulations" (Sputnik, 2019).

Russia particularly stressed the Ukrainian source of Belarusian export. In January 2018, deputy head of Rosselhoznadzor Julia Melano specifically identified Ukraine as a source of Belarusian re-export. 15 thousand tonnes of Ukrainian meat was reexported by Belarus in 2015-2016 by estimates of the Russian cities of Smolensk and Bryansk officials (RBC, 2018). Belarus supplied $84 \%$ of cheese imports to Russia, at least a quarter of which was a re-export from Ukraine (DW, 2018). According to Dankvert, it is a "legalization of Ukraine's cheese via Belarus, specifically Beltamozhservis" (ibid.). Russia's Minister of Agriculture Aleksandr Tkachev called for radical measures against smuggling including confiscation of property and criminal cases (Belsat, 2018a). The Ukrainian official statistics reported the rise of import of agriculture by four times in 2013-2017.

Subsequently, Russian officials and media growingly pointed at the benefectors in Belarusian elites with profits of up to one billion per year. As media reported, key players in the market were former top officials closely connected to Aleksandr Lukashenko. Vasily Dementey, former head of the State Customs Service and deputy head of KGB, resigned in 2016 and became a chief of a large logistic company. Former colleagues of Viktor Lukashenko, his former assistant Aleksandr Zaycev, the tobacco magnate Aleksey Aleksin and oil trader Nikolay Vorobey (Palivoda, 2019), run the other key company. Their company "Bremino Group" re-exported Ukrainian food to Russia and Russian oil products to Ukraine and received numerous benefits from the state in 2018-2019. In 2019, presidential decree N106 "On the creation of special economic zone Bremino-Orsha" created a special legal zone and offered a number of additional financial and tax advantages for the company. In 2018, Russia supplied Belarus with some 3 million tonnes of oil products, which mostly benefitted private companies ran by Vorobey and Aleksin. They were found re-exporting Russian oil products, specifically diesel and heavy oil to Ukraine (Iaroshevich, 2019).

Belarus still blamed Russia. Lukashenko stressed in 2018, "[smuggling] is a headache for us. We do an enormous work to defend Russia's interests. (...) Instead of gratitude, we are criticized for bad work" (Vedomosti, 2018). Belarus occasionally accused Moscow of letting situation out of control. In February 2017, Lukashenko ordered to start a criminal case against the head of Rosselhoznadzor (BBC, 2017).

Previously, Minsk's boundary-testing behaviour provoked conflicts, but it maintained loyalty. Russia usually agreed with Belarus' conditions at large (see also Moshes, 
2019). However, since 2017, Russia’s positioned changed dramatically. Russia viewed Belarusian behavior as boundary breaking and reacted accordingly. It growingly increased its pressure, cut its energy benefits to Belarus and offered new integration initiatives, which Belarus considered to be too costly politically. In late 2017, Moscow proposed to harmonize fiscal and customs policies to fix the problem of smuggling. However, according to Mihail Babich Russian proposals were consistently ignored. In turn, in 2018, Moscow cut the supplies of oil products to Belarus. Highlighting reexport of oil products to Ukraine, Minister of Energy Novak questioned the necessity of continuing their supply to Belarus.

Lukashenko reacted harshly, comparing Russia's actions with sanctions: "they slap us in the left cheek and we turn the other to them" (Naviny.by 2019). Minsk's threats were not credible this time. In late 2018, Moscow offered to intensify political and economic integration under the auspices of the Union State. Russia underlined that the restoration of the "old" benefits is possible only under conditions of "further integration" in customs, financial, tax and economic spheres. Moscow initiated "tax maneuver", which restored duties on its crude oil supplies to Minsk. Oil supplies were maintained in the same volume, yet the negotiations for the longer-term gas and oil prices were postponed until 2020. In 2020, they were extended only for a year. First Vice-Prime Minister Anton Siluanov connected Moscow's support to the prospects of integration and the problem of smuggling: "Tax maneuver is our domestic issue. (...) We do not trust your customs services - so let our customs work there as well, let's start the exchange of information" (Belsat, 2018b). The continuation of the previous benefits in 2020 was made conditional: "It is huge money and in return for integration, we are ready to pay" (ibid.).

Moscow rejected giving new loans to Minsk and clearly delineated possible amount of subsidies to Minsk based on agreements on new 31 road maps to be completed during 2020. According to Russian president's spokesperson Dmitry Peskov, "Russia does not impose any sanctions" nor "twists any arms" - it is just a "bilateral work" (Kommersant, 2019).

\section{Conclusion}

This article investigates the effects of RussiaEU-Ukraine sanction regimes on Belarusian foreign policy and its relations with Russia, EU and Ukraine. Belarusian foreign policy and its responses raised questions about nature and motivations, as well as outcomes. Belarus announced its neutral stance in Russia-Ukraine conflict and proclaimed its intention to help the sides to resolve the conflict. It offered a set of contradictory measures, dubbed as hedging, balancing and confidence-building. 
Belarus pledged its economic, diplomatic and security support to Ukraine. Its security guarantees for Ukraine and a pledge of minor domestic liberalization, which were altogether understood as an intention to distance from more assertive Russia, offered the West an opportunity to start normalization with Minsk. At the same time, Minsk promised to stay committed to the political and security alliance with Russia and offered its assistance in overcoming possible deficits of goods in its market and ensuring the counter-sanctions regime.

This article argues that Belarus attempts to exploit mutually exclusive opportunities failed and led to opposite effects. In the Western direction, Belarus achieved some quick improvements, which remained small in scale and did not meet expectations. Belarus expected to receive unconditional assistance for its stabilizing security role in the region, but the West was not ready to support Minsk without minor liberalization. BelarusUkraine relations stagnated and eventually deteriorated. Despite Ukraine's natural role as a hedging partner vis-a-vis Russia and their overlapping political and security interests, as normalization with the EU were launched, Belarus quickly neglected the Ukrainian direction of its foreign policy. Confidence building measures were severely undermined by trade conflicts. Economic cooperation was sidelined and instead of creating joint enterprises to access Russian market Minsk focused on ripping the benefits of Ukraine's position and unilaterally use its ability to access Russian market.

The Russia-Belarus alliance was affected most profoundly. Minsk attempts to maintain a status quo in Belarus-Russia relations failed. If trade frictions, rapprochement with the EU and non-recognition of the Crimea was perceived rather as boundary-testing, and was "understood" by Russia, Minsk's "free riding" on countersanctions regime despite its initial commitment to prevent smuggling was perceived as a major breach of trust and inter-alliance obligations. An open profiteering of the Belarusian regime on smuggling was viewed as disloyalty and boundary challenging. As a result, Russia's approach to Minsk evolved from "unconditional" financial and economic support to stricter conditionality under principle "same for less" (see also Moshes, 2019). Russia gradually removed Minsk's economic and financial benefits and conditioned their return to deeper integration between the partners and concessions from Belarusian side. That de-facto ended the status quo on Belarusian terms in Belarus-Russia relations.

\section{Bibliography}

Balashova, Anna and Natalia Novopashina. "Pobeda nad ustricami: tamozhnja raskryla krupnejshuju shemu vvoza sankcionki”. RBC (2017) (online) [Accessed: 24/10/2019] https://www.rbc.ru/business/28/08/2017/596dc0779a7947392c26 81 f1?from=main 
Baldwin, David. Economic Statecraft. Princeton: Princeton University Press, 1985.

BBC. "Lukashenko ordered to start a criminal case against the head of Rosselhoznadzor" (2017) (online) [Accessed: 21/04/2020] https://www.bbc.com/russian/news-38854071

Belsat. "Rossija - nasha beda, otomstim sankcionkoj!” Belsat (2017) (online) [Accessed: 24/10/2019] https://belsat.eu/ru/in-focus/rossiya-nasha-beda-otomstimsanktsionkoj/

Belsat. "Siluanov zajavil, chto Belarus' poterjala doverie sojuznika v Rossii”. Belsat (2018a) (online) [Accessed: 24/10/2019] https://belsat.eu/ru/news/siluanov-zayavil-chto-belarus-poteryala-doverie-soyuznika-v-rossii/

Belsat. "Russian PM Medvedev insists on deepening integration, Minsk wants to solve economic issues first”. Belsat (2018b) (online) [Accessed: 24/10/2019] https://belsat.eu/en/news/russian-pm-medvedev-insists-on-deepening-integration-minskwants-to-solve-economic-issues-first/

Belsat. "Iabloki v Rossiyu - shans dlya kontrabandistov vysshego zvena?" Belsat (2019a) (online) [Accessed: 19/04/2020] https://belsat.eu/ru/in-focus/yabloki-vrossiyu-shans-dlya-kontrabandistov-vysshego-zvena-rassledovanie-belsata/

Belsat. "Kto vo vlasti pokryvaet kontrabandu" (2019b) Belsat (online) [Accessed: 12/04/2020] https://belsat.eu/ru/programs/kto-vo-vlasti-pokryvaet-kontrabanduiz-belarusi-v-rossiyu-rassledovanie-belsata/

Belta. "Address of the President to the Belarusian people and the National Assembly” (2015) (online) [Accessed: 12/04/2019] http://president.gov.by/en/news_en/ view/belarus-president-to-address-nation-parliament-on-29-april-11303/

Belta. "Lukashenko: Belarus' zainteresovana v vystraivanii dobrososedskikh otnosheniy s ES" (2019a) (online) [Accessed: 12/04/2019] https://www.belta.by/presi$\mathrm{dent/view/lukashenko-belarus-zainteresovana-v-vystraivanii-dobrososedskih-ot-}$ noshenij-s-es-370504-2019/

Belta. "Bolton describes meeting with Belarus president as very important" (2019b) (online) [Accessed: 12/04/2019] https://eng.belta.by/politics/view/bolton-describes-meeting-with-belarus-president-as-very-important-123726-2019/

Bohdan, Siarhei. "Belarus Helps Ukraine with Military Equipment". Belarus Digest (2015) (online) [Accessed: 24/10/2019] https://belarusdigest.com/story/belarushelps-ukraine-with-military-equipment/

Bohdan, Siarhei. “Threats to Belarus, Ukrainian Border, Cooperation with Kazakhstan”. Belarus Digest (2016) (online) https://belarusdigest.com/story/threats-tobelarus-ukrainian-border-cooperation-with-kazakhstan-belarus-security-digest/

Booth, Ken and Nicholas Wheeler. The Security Dilemma: Fear, Cooperation, and Trust in World Politics. New York, NY: Palgrave McMillan, 2008.

Catalinac, Amy. "Why New Zealand took itself out of ANZUS: Observing 'Opposition for Autonomy' in Asymmetric Alliances”. Foreign Policy Analysis, vol. 6, issue 3 (2010), pp. 317-338. 
Deitelhoff, Nicole and Linda Wallbott. "Beyond soft balancing: small states and coalition-building in the ICC and climate negotiations" Cambridge Review of International Affairs, vol. 25, issue 3 (2012).

Censor.net. "Ukraina i Belarus' prinyali polozheniye o demarkatsii obshchey granitsy". Censor.net(2014) (online) [Accessed: 08/09/2020] https://censor.net/ru/news/296088/ ukraina_i_belarus_prinyali_polojenie_o_demarkatsii_obscheyi_granitsy

Dursun-Özkanca, Oya. Turkey-West Relations. Cambridge University Press, 2019.

DW. "Belarus arrests dozens in crackdown, claims weapons found". Deutsche Welle (2017) [Date accessed 12.09.2019] https://www.dw.com/en/belarus-arrests-dozens-in-crackdown-claims-weapons-found/a-38099994

DW. "Chetvert' vseh syrov mogli byt' vvezeny v Rossiju kontrabandoj iz Ukrainy". Deutsche Welle (2018) (online) [Accessed: 12/09/2019] https://www.dw.com/ru/ четверть-всех-сыров-могли-быть-ввезены-в-россию-контрабандойиз-украины/а-42298279

Dzerzhinskaya, Luda. "Kak rabotaet rynok sankcionki". Bumaga (2015) (online) [Accessed: 12/09/2019] https://paperpaper.ru/say-cheese/

Gazeta.ru. "Putin obyasnil nezhelaniye Lukashenko priznat' Krym rossiyskim” (2020) (online) [Accessed: 12/04/2020] https://www.gazeta.ru/ politics/2020/03/19_a_13011367.shtml

Gnedina, Elena. "'Multi-Vector' Foreign Policies in Europe: Balancing, Bandwagoning or Bargaining?”. Europe Asia Studies, vol. 67, issue 7 (2015), pp. 1.007-1.029.

Haukkala, Hiski, Carina van de Wetering and Johanna Vuorelma. Trust in International Relations. Routledge, 2019.

Iaroshevich, Aleksandr. "Moskva zakryla Minsku serye shemy po nefteproduktam. Kto na nih zarabatyval". Naviny.by (2018) (online) [Accessed: 24/10/2019] https://naviny.by/article/20181011/1539260124-moskva-zakryla-minsku-seryeshemy-po-nefteproduktam-kto-na-nih

Iaroshevich, Aleksandr. "Orshanskij ofshor. Kto okazhetsja v shokolade". Naviny.by (2019) (online) [Accessed: 24/10/2019] https://naviny.by/ article/20190116/1547620618-orshanskiy-ofshor-kto-okazhetsya-v-shokolade

IMF. "Republic of Belarus". IMF Country Report, issue 16/298 (2016) (online) [Accessed: 19/04/2020] https://www.imf.org/external/pubs/ft/scr/2016/cr16298.pdf

Interfax 2015. "Dlya mezhdunarodnogo soobshchestva". (2015) (online) [Accessed: 19/04/2020] https://interfax.by/news/policy/vneshnyaya_politika/1196025/

Koga, Kei. "The Concept of 'Hedging' Revisited: The Case of Japan's Foreign Policy Strategy in East Asia's Power Shift". International Studies Review, vol. 20, issue 4 (2018), p. 633-660.

Kommersant. "Lukashenko obvinil rossiyskiy biznes $\mathrm{v}$ postavkakh sanktsionnykh produktov cherez Belorussiyu". Kommersant (2019) (online) [Accessed: 08/09/2020] https://www.kommersant.ru/doc/3940006 
Kononovich, Evgeny. "Rost postuplenij v bjudzhet, 'sankcionnye' tovary i narkotiki. Prezident obsudil rabotu tamozhni s glavoj GTK”. SB Segodnya (2018) (online) [Accessed: 12/08/2019] https://www.sb.by/articles/lukashenko-o-sanktsionnykhtovarakh-vmesto-blagodarnosti-nachinayut-predyavlyat-nam-pretenzii.html

Kuiun, Sergey. "Manevry hitrogo tancora". Zerkalo Nedeli (2018) (online) [Accessed: 24/10/2019] https://zn.ua/energy_market/manevry-hitrogo-tancora-280499_. html

Lobell, Steven, Neal Jesse and Kristen Williams. "Why do secondary states choose to support, follow or challenge?" International Politics, vol. 52, issue 2 (2015), pp. 146-162.

Meister, Stefan. "Hedging and Wedging: Strategies to Contest Russia's Leadership in Post-Soviet Eurasia”, in: Ebert H., Flemes D. (eds) Regional Powers and Contested Leadership. Palgrave Macmillan, 2018.

Melyantsou, Dzianis. "Belarus Foreign Policy Index". BISS (2015) (online) [Accessed: 24/10/2019] https://belinstitute.com/en/node/2687

Melyantsou, Dzianis. "Minsk Process: Can the Success of the Minsk Platform for Negotiations Be Further Developed?” minskdialogue.by (2017) (online) [Accessed: 12/04/2020] https://minskdialogue.by/en/research/analitycs-notes/minsk-process-can-the-success-of-the-minsk-platform-for-negotiations-be-further-developed

Mir24. "Lukashenko obeshchayet zashchishchat' Rossiyu, kak svoyu territoriyu” (2014) (online) [Accessed: 12/04/2020] https://www.youtube.com/ watch? $=\mathrm{I} 6 \mathrm{~K} 9 \mathrm{nBt} 7 \mathrm{~d} \_\mathrm{o}$

Mk.ru. "Lukashenko: Belorussiya mozhet mgnovenno otpravit' v Novosibirsk 120 tonn grechki" (2014) (online) [Accessed: 12/04/2020] https://www.mk.ru/economics/2014/11/27/lukashenko-belorussiya-mozhet-mgnovenno-otpravit-v-novosibirsk-120-tonn-grechki.html

Moshes, Arkady. "Can Belarus Perform a Real Balancing Act between Russia and the West?” PONARS Eurasia (2017) (online) [Accessed: 04/08/2019] https://www. ponarseurasia.org/article/can-belarus-perform-real-balancing-act-between-russiaand-west

Moshes, Arkady. "All Quiet in Russian-Belarusian Relations”. PONARS Eurasia Policy Memo, issue 607 (2019).

Moshes, Arkady and Ryhor Nizhnikau. "A Partnership Not in the Making”. PONARS Eurasia Policy Memo, issue 557 (2018).

Moskalenko, German. "Posol RF v Belarusi Aleksandr Surikov: Rejeksport sankcionki ne obhoditsja bez rossijskogo biznesa”. Soiuznoe Veche (2018) (online) [Accessed: 03/10/2019] https://www.souzveche.ru/articles/our-union/43107/

Naviny.by. "Rossel'hoznadzor raskryl novuju shemu kontrabandy iz Belarusi”. Naviny.by (2019) (online) [Accessed: 24/11/2019] https://naviny. 
by/new/20190424/1556130521-v-gomele-vynesen-prigovor-dvum-opgza-postavki-sankcionki-v-rossiyu

Onliner. "Lukashenko o sankcijah v otnoshenii belorusskih produktov", Onliner.by (2014) (online) [Accessed: 01/10/2019] https://people.onliner.by/2014/11/27/ lukashenko-141

Onliner. "Lukashenko: Ja gotov k bolee zhestkim reformam, chem trebuet MVF. Gotovy li Vy k nim". Onliner.by (2016) (online) [Accessed: 24/08/2019] https:// people.onliner.by/2016/10/07/lukashenko-180

Palivoda, Andrey. "Neftjanaja pikirovka: cherez chto predstoit projti Ukraine?" Levyi Bereg (2019). (online) [Accessed: 24/11/2019] https://lb.ua/ world/2019/04/25/425479_neftyanaya_pikirovka_cherez.html

Pape, Robert. "Soft Balancing Against the United States". International Security, 30, issue 1 (2005), p. 7-45.

Portela, Clara. "Belarus and the European Union: Sanctions and partnership?" Comparative European Politics, vol. 9, issue 4 (2011), p. 486-505.

Rathbun, Brian. "Before Hegemony: Generalized Trust and the Creation and Design of International Security Organizations". International Organizations, vol. 65, issue 2 (2011).

RBC. "Vlasti zapodozrili do $25 \%$ syrov v Rossii v ukrainskom proishozhdenii". $R B C$ (2018). (online) [Accessed: 24/10/2019] https://www.rbc.ru/business/25/01/201 8/5a673b0c9a79470c31b4a062

RBC. "Lukashenko nazval Zapad i NATO garantami suvereniteta Belorussii". RBC (2019) (online) [Accessed: 18/05/2020] https://www.rbc.ru/politics/24/12/2019/ $5 \mathrm{e} 01 \mathrm{f0} 029 \mathrm{a} 7947 \mathrm{e} 3 \mathrm{f} 7 \mathrm{~b} 7 \mathrm{a} 06 \mathrm{c}$

RIA Novosti. "Belorussija gotova zamenit" Evropu v jeksporte produktov v Rossiju”. RIA Novosti (2014) (online) [Accessed: 29/09/2019] https://ria. $\mathrm{ru} / 20140807 / 1019101308 . \mathrm{html}$

RIA Novosti. "Lavrov: RF zainteresovana $\mathrm{v}$ normalizatsii otnosheniy Belorussii i Zapada”. RIA Novosti (2015) (online) [Accessed: 18/05/2020] https://ria. ru/20150824/1204123835.html

RIA Novosti. "Kuda priachut sankcionku". RIA Novosti (2018) (online) [Accessed: 24/10/2019] https://ria.ru/20180806/1525986519.html

Ross, Robert. "Sino-Russian relations: the false promise of Russian balancing". International Politics (2019).

Ruzicka, Jan and Vincent Keating. "Going global: Trust research and international relations". Journal of Trust Research, vol. 5, issue 1 (2015).

Segodnya. "Ya krovno zainteresovan v edinstve Ukrainy". (2014a) (online) [Accessed: 12/04/2020] https://www.segodnya.ua/politics/lukashenko-ya-krovno-zainteresovan-v-edinstve-ukrainy-526990.html

Segodnya. "Boevikov nuzhno unichtozhat". (2014b) (online) [Accessed: 12/04/2020] 
https://www.segodnya.ua/politics/lukashenko-boevikov-kotorye-voyuyut-protivukraincev-nuzhno-unichtozhat-527051.html

Sejersen, Mikkel. "Democratic sanctions meet black knight support: revisiting the Belarusian case". Democratization vol. 26, issue 3 (2019), p. 502-520.

Sputnik. "Babich: Rossiya teryayet milliony dollarov iz-za sanktsionki iz Belarusi". Sputnik, (2019) (online) [Accessed: 08/09/2020] https://sputnik.by/economy/20190117/1039637628/Babich-Rossiya-teryaet-milliony-dollarov-iz-zasanktsionki-iz-Belarusi.html

Tut.by. "Putin poprosil Lukashenko s ponimaniyem otnestis' $\mathrm{k}$ rossiyskomu boykotu zapadnykh produktov" (2014) (online) [Accessed: 12/04/2020] https://news.tut. by/politics/410232.html

Tut.by. "Peregovory po Ukraine v Minske: mneniya ekspertov razdelilis"” (2015) (online) [Accessed: 12/04/2020] https://news.tut.by/politics/409103.html

Tut.by. "Lukashenko sobirayetsya prorubit' 'okno v Evropu" (2019) (online) [Accessed: 12/04/2020] https://news.tut.by/economics/659398.html

Vedomosti. "Kak Belorussija snabzhaet Rossiju sankcionnymi produktami". (2017) (online) [Accessed: 21/10/2019] https://www.vedomosti.ru/business/ articles/2017/03/27/682805-belorussiya-sanktsionnimi-produktami

Vedomosti. "Lukashenko obvinil rossiyskiy biznes $\mathrm{v}$ postavkakh sanktsionnykh produktov cherez Belorussiyu”. (2018) (online) [Accessed: 08/09/2020] https:// www.vedomosti.ru/politics/news/2018/07/17/775720-lukashenko

Washington Post. "Putin has set his eyes on Belarus. The West can help it resist". (2020) (online) [Accessed: 18/05/2020] https://www.washingtonpost.com/opinions/global-opinions/putin-has-set-his-eyes-on-belarus-the-west-can-help-it-resist/2020/02/10/bcb707d6-4c2f-11ea-bf44-f5043eb3918a_story.html

Wilson, Andrew. "Belarus Wants Out". Foreign Affairs. (2014) (online) [Accessed: 12/04/2020] https://www.foreignaffairs.com/articles/belarus/2014-03-20/belarus-wants-out

Wilson, Andrew. "Softly, softly Belarus". New Eastern Europe, issue 33 (2018).

ZN.ua. "Bor'ba za baki”. Zerkalo Nedeli (2018) (online) [Accessed: 24/10/2019] https://zn.ua/energy_market/borba-za-baki-273375_.html 




